\title{
Bioaccumulation and Human Risk Assessment of Heavy Metals in Oreochromis niloticus and Clarias gariepinus Fish Species from the Golinga Reservoir, Ghana
}

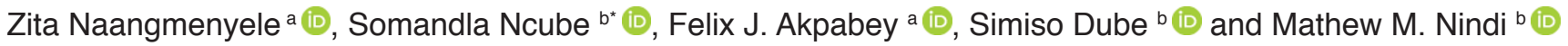 \\ ${ }^{a}$ Council for Scientific and Industrial Research-Water Research Institute, Tamale, NR, Ghana \\ ${ }^{b}$ Chemistry Department, The Science Campus, University of South Africa, Pretoria, South Africa
}

Received 25 September 2020 , revised 24 December 2020, accepted 25 December 2020

\begin{abstract}
The Nile tilapia (Oreochromis niloticus) and African catfish (Clarias gariepinus) from the Golinga reservoir in Northern Ghana are consumed as an alternative source of protein. In the current study, levels of selected metals (As, Cd, Fe, Co, Cr, Cu, Mn, Mo, Ni and $\mathrm{Pb}$ ) in the two fish species and the fish condition were determined, and potential human health effects assessed. The metal concentrations in the edible fish muscles ranged from $0.16 \mathrm{mg} \mathrm{kg}^{-1}(\mathrm{Mn})$ to $101 \mathrm{mg} \mathrm{kg}^{-1}(\mathrm{~Pb})$. The weight-length relationships showed that both fish were growing isometrically, and bioaccumulation of metals from the reservoir was considered insignificant with bioconcentration factors below 100 except for Mn, whose value was 161 in the gills of Oreochromis niloticus. The health risk assessment showed that $\mathrm{Pb}, \mathrm{Cd}$ and As had Target Hazard Quotient values above 1 for both fish species, with that of As being as high as $\mathbf{1 9 . 6}$ for Oreochromis niloticus. The target cancer risk values for $\mathrm{As}, \mathrm{Cd}, \mathrm{Cr}$ and $\mathrm{Pb}$ were above the non-risk threshold of $\leq 10^{-6}$, indicating the risk of cancer developing over the years due to fish consumption. The metal concentration in the fish in the reservoir should therefore be constantly monitored and potential health risks associated with frequent consumption of the fish assessed.
\end{abstract}

KEYWORDS

fish; health risk assessment; Nile tilapia; Target Hazard Quotient; trace metals

\section{Introduction}

The Golinga reservoir has been a source of socio-economic survival for local communities in the Tolon District and other neighbouring districts and towns in the Northern region of Ghana, notably the Kumbungu District and Tamale Metropolitan. Application of agrochemicals, especially pesticides and fertilisers, and surface runoff from domestic and wastewater effluents from the communities residing on the reservoir watershed may lead to contamination. While the fish from the reservoir is commonly consumed for their high protein value, the accumulation of heavy metals in fish muscles and organs is possible, which negatively impacts the health of the consumers. Therefore, the determination of heavy metals in the fish is necessary to assess the extent of metal bioaccumulation and perform a human health risk assessment, especially in areas where fish is frequently consumed. In Ghana, the per capita fish consumption is estimated at $28 \mathrm{~kg} \mathrm{yr}^{-1}$, which is well above the African and world per capita averages of 10.5 and $18.9 \mathrm{~kg} \mathrm{yr}^{-1}$, respectively. ${ }^{1}$ Furthermore, fish accounts for as much as $60 \%$ of animal protein in the average Ghanaian diet and $22.4 \%$ of household food expenditures. It is estimated that the consumption rate is high in regions where fish from local dams form a major source of animal protein. As of 2010, the Tolon District population was 72 990, that of the Tamale Metropolis was 223252 while the Northern Region as a whole is home to 2479461 inhabitants. $^{2}$

The Agency for Toxic Substances and Disease Registry has identified some heavy metals notably $\mathrm{As}>\mathrm{Pb}>\mathrm{Cd}>\mathrm{Ni}>\mathrm{Zn}$ $>\mathrm{Cr}>\mathrm{Cu}>\mathrm{Mn}$ in descending order as priority metals. ${ }^{3}$ The World Health Organization (WHO) and Food and Agricultural Organization (FAO) have provided guideline values for acceptable levels of some heavy metals in food sources. ${ }^{4}$ In this regard, various studies have been reported in the past decade to determine levels of heavy metals in fish species worldwide for health risk assessment towards humans, ${ }^{3-11}$ heavy metal poisoning for fish ${ }^{12-17}$ and as a biomarker for environmental contamination. ${ }^{18-22}$ Most of these studies have been done on commercial fish collected mainly from the sea and estuaries, while river fish ${ }^{22-24}$ and cultured fish ${ }^{25,26}$ are also mentioned.

In Africa, most communities catch fish species found in local dams for domestic consumption, while some are sold in nearby towns. However, monitoring of heavy metals in fish remains limited, with only a few studies reported. A few human health risk assessment studies due to heavy metals in non-commercial fish have been done for fish collected from African rivers, dams and reservoirs. ${ }^{21,27,28}$ Thus, this study investigated the levels of heavy metals (concentrations and bioaccumulation factors) and determined human health risk assessment (hazard quotients and cancer risk) due to consumption of the Oreochromis niloticus and Clarias gariepinus, respectively. The two freshwater fish species breed naturally in the Golinga reservoir and are consumed locally by the indigenes and nearby communities.

\section{Experimental}

\subsection{Chemicals and Reagents}

Nitric acid $(70 \%, v / v)$ and hydrochloric acid $(32 \%, v / v)$ were of analytical grade and purchased from Sigma-Aldrich (Johannesburg, South Africa). Certified reference standards for elements were purchased from Supelco Belefonte, USA. Ultrahigh purity water was generated at $18.2 \mathrm{M} \Omega \mathrm{cm}^{-1}$ from a MilliQRO4 system 117 (Millipore, Bedford, MA, USA).

\subsection{Instrumentation}

An Agilent ICP-OES 700 Series (Agilent Technologies, Santa 
Clara, CA, USA) was used for metal analysis. Calibration of the instrument was done in the $0.1-5 \mathrm{mg} \mathrm{L}^{-1}$ range. All the fish samples were digested using BIOBASE MLS-1200 MEG Multifunctional Bolt Design microwave digester (BIOBASE, Qingdao, China). The digester can hold $8 \times 100 \mathrm{~mL}$ bomb vessels made of polytetrafluoroethylene, and its maximum operating power is $1000 \mathrm{~W}$.

\subsection{Sampling and sample preparation}

Water and fish samples were collected from the Golinga Reservoir located in the Tolon District, Northern Region of Ghana. The source of water is the Kornin River and inflows from surface runoffs from the surrounding communities. All the samples were initially handled and preserved at the Council for Scientific and Industrial Research-Water Research Institute laboratory in Tamale, Ghana. They were stored in the freezer at $-21^{\circ} \mathrm{C}$ and eventually transported to the University of South Africa, Johannesburg, South Africa, for analysis.

The water samples were taken at four different points into $500 \mathrm{~mL}$ polyethylene bottles, stored in an iced chest at $4^{\circ} \mathrm{C}$ and transported immediately to the laboratory. The water samples were filtered through $0.45 \mu \mathrm{m}$ syringe filters and preserved by adding $5 \mathrm{~mL} \mathrm{HNO}_{3}$. These samples were then transported to the University of South Africa, South Africa. On arrival, the water samples were immediately analysed for metals. Fresh fish (20 for each of the two species) were purchased from locals at the Golinga reservoir. At the laboratory in Ghana, the fish were weighed, and their fork length recorded. The fish were then dissected to separate various parts. The edible muscles of each fish species were then blended using a home blender and then stored in the freezer at $-21^{\circ} \mathrm{C}$. The same was done for the gills. The fish muscles and gills were eventually transported to the University of South Africa, South Africa, for analyses. Upon arrival, the samples were immediately freeze-dried, ground into a fine powder $(<150 \mu \mathrm{m}$ particle size), acid digested and finally analysed for metals.

\subsection{Sample digestion}

Dry powdered fish samples $(500 \mathrm{mg}$ ) were weighed into microwave digestion bomb vials. $9 \mathrm{~mL} \mathrm{HNO}_{3}$ and $3 \mathrm{~mL} \mathrm{HCl}$ were added to the samples. The digestion bomb vials were then placed in the microwave digester, and digestion was done at $175^{\circ} \mathrm{C}$ for $45 \mathrm{~min}$. Both fish muscles and gills were digested in triplicate. The vials were then allowed to cool down to below $70^{\circ} \mathrm{C}$ before opening the digester to minimise the loss of volatile elements. The digestate was transferred into $50 \mathrm{~mL}$ volumetric flasks and made up to the mark using ultra-high pure water. The digestate was then filtered through $0.2 \mu \mathrm{m}$ syringe filters into ICP sample vials for analysis.

\subsection{Fish condition}

The condition of the fish from the reservoir was estimated using the weight-length relationship based on the standard allometric equation (Eq. 1), where $\mathrm{W}$ is weight and $\mathrm{L}$ is length. The linearised logarithmic form of Eq. 1 results in Eq. 2. A plot of $\log \mathrm{W}$ vs $\log \mathrm{L}$ should give the parameters $\mathrm{a}$ and $\mathrm{b}$ from the $y$-intercept and the slope of the plot, respectively. On the other hand, Eq. 1 has also been simplified as Fulton's condition factor (FCF) (Eq. 3), in which the parameter is a constant and is given a standard value of 3 .

$$
\mathrm{W}=\mathrm{aL}^{\mathrm{b}}
$$

$\log \mathrm{W}=\log \mathrm{a}+\mathrm{blog} \mathrm{L}$

$\mathrm{FCF}=100 \times \mathrm{W} / \mathrm{L}^{3}$
When $b=3$, Fulton's condition factor is equal to 1 $(\mathrm{FCF}=1.0)$, and the growth of the fish is considered isometric resulting in an ideal shape. The allometric growth is positive, and the fish is healthier if FCF $>1$ and negative and leaner if FCF $<1$. In the weight-length relationship, the deviation of the $b$-parameter from the standard value of 3 is used to estimate the fish condition. In this regard, when $b>3$ the fish is fatter and thinner when $b<3$.

\subsection{Bioaccumulation factors}

The accumulation of metals by fish from aqueous environments occurs mainly through the food chain, ion exchange across the gills during breathing and ingestion of suspended particulate matter. The amount accumulated depends on various factors, such as the pollution status of the habitat and metal bioavailability. Bioaccumulation is also related to the environmental conditions of water, such as $\mathrm{pH}$ and temperature, and the fish species' physiology, age and eating habits. The amount of metals accumulated in fish, as a ratio of the amount existing in aqueous solution, is defined as the bioaccumulation or bioconcentration factor (BF) and is calculated using Eq. $4^{29}$. The fish would have accumulated the metal in its body if $\mathrm{BF}>1$. However, the accumulation is still considered insignificant if $\mathrm{BF}<100 .^{29}$

$$
\mathrm{BF}=\mathrm{C}_{\mathrm{F}} /\left(5.26 \times \mathrm{C}_{\mathrm{W}}\right)
$$

where $\mathrm{BF}$ is the bioaccumulation factor, $\mathrm{C}_{\mathrm{F}}$ is the concentration of a metal in a fish organ $\left(\mathrm{mg} \mathrm{kg}^{-1}(\mathrm{dw})\right), 5.26$ is the fish wet weight concentration factor, assuming $81 \%$ fish water content and $C_{W}$ the concentration of a metal in water.

\subsection{Health risk assessment}

The Estimated Daily Intake (EDI) of each metal due to the fish consumption from the reservoir was calculated using Eq. 5 . The per capita consumption of fish in Ghana is currently estimated at $28 \mathrm{~kg} \mathrm{yr}^{-1}$. $^{1}$ The community of Golinga consumes the two fish species from the reservoir at similar rates, which then equates to $0.0384 \mathrm{~kg} \mathrm{day}^{-1}$ per fish species. Introducing the average fish dry factor of 0.190 based on $81 \%$ fish water content eventually equates to $7.29 \mathrm{~g} \mathrm{day}^{-1}(\mathrm{dw})$ per fish species. Therefore, $7.29 \mathrm{~g}$ day $^{-1}(\mathrm{dw})$ was used as the fish ingestion rate (FIR) in all calculations.

$$
\mathrm{EDI}=\left(\mathrm{C}_{\mathrm{m}} \times \mathrm{FIR}\right) / \mathrm{BW}
$$

where EDI is the estimated daily intake of an element $\left(\mathrm{mg} \mathrm{kg}^{-1}\right.$ day $\left.^{-1}\right), C_{m}$ is the mean concentration of the element in the fish muscle $\left(\mathrm{mg} \mathrm{kg}^{-1}(\mathrm{dw})\right)$, FIR is the fish ingestion rate per person $\left(7.29 \times 10^{-3} \mathrm{~kg}\right.$ day $\left.^{-1}(\mathrm{dw})\right)$, and BW is the bodyweight of an adult $(70 \mathrm{~kg})$ in Ghana.

The potential non-carcinogenic health risk of each studied metal due to fish consumption was estimated as the Target Hazard Quotient (THQ) using Eq. 6. The THQ values represent the ratio of the estimated daily dose versus a reference dose $\left(\operatorname{Rf}_{\mathrm{D}}\right)$. If the ratio is $>1$, then the exposed population may experience potential health risks over their lifetime. Conversely, the health risks are unlikely if THQ $<1$ and any potential health effects are considered non-carcinogenic. Potential carcinogenic risks were calculated as Target Cancer Risks (TCRs), based on Cancer Slope Factor (CSF) values of metals with known carcinogenic effects, using Eq. 7. These metals are $\mathrm{As}, \mathrm{Cd}, \mathrm{Pb}$ and $\mathrm{Cr}$, and their CSF values are $1.5,6.3,0.0085$ and $0.5 \mathrm{~kg}$-day $\mathrm{mg}^{-1}$, respectively. ${ }^{30}$ The TCR values represent various cancer risk categories ranging from low risk $\left(\mathrm{TCR} \leq 10^{-6}\right)$ to high risk $\left(10^{-1} \geq \mathrm{TCR} \geq 10^{-3}\right){ }^{24,30}$ Risk is very high when TCR $\geq 10^{-1}$ indicating that consumption of such food will result in cancerous health effects. Estimating the permissible fish consumption rate for the communities relying on the fish from the Golinga reservoir was done using 
Eq. 8. This estimation was used to determine the maximum amount of fish that can be consumed annually by an individual without the potential for health side effects, based on the measured concentrations in the fish muscles.

$$
\mathrm{THQ}=\left(\mathrm{EF} \times \mathrm{ED} \times \mathrm{FIR} \times \mathrm{C}_{\mathrm{m}}\right) /\left(\mathrm{Rf}_{\mathrm{D}} \times \mathrm{BW} \times \mathrm{AT}\right)
$$

where THQ is the Target Hazard Quotient, EF is exposure frequency (365 days $\left.\mathrm{yr}^{-1}\right)$, ED is exposure duration (60 years), AT is the average time ( 365 days/year $\times 60$ years $=21900$ days) and $\mathrm{Rf}_{\mathrm{D}}$ is the reference daily oral intake $\left(\mathrm{mg} \mathrm{kg}^{-1} \mathrm{day}^{-1}\right)$ of the element according to $\mathrm{WHO} / \mathrm{FAO}^{30}$.

$$
\mathrm{TCR}=\left(\mathrm{EF} \times \mathrm{ED} \times \mathrm{FIR} \times \mathrm{C}_{\mathrm{m}} \times \mathrm{CSF}\right) /(\mathrm{BW} \times \mathrm{AT})
$$

where TCR is the Target Cancer Risk due to a carcinogenic element and CSF is the Cancer Slope Factor of the carcinogenic

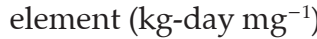

$$
\mathrm{CR}_{\lim }=\left(\mathrm{Rf}_{\mathrm{D}} \times \mathrm{BW} \times \mathrm{EF} \times 5.26\right) / \mathrm{C}_{\mathrm{m}}
$$

where $\mathrm{CR}_{\lim }$ is the maximum permissible fish consumption limit ( $\mathrm{kg} \mathrm{yr}^{-1}$ per person), and 5.26 is the wet weight concentration factor assuming $81 \%$ fish water content.

\subsection{Statistical analysis}

A one-way analysis of variance (ANOVA) was performed on Minitab 18.1.0 to compare the mean concentration of each metal in the two species and see if there was any variance in the gills and muscles of each species at a 95\% significance level. Three values of a metal concentration obtained from triplicate analysis of a homogenised sample were used in each case. ANOVA was done in conjunction with the Tukey test ${ }^{31}$ to identify the source of variance, especially for those concentrations deemed significantly different at $95 \%$ confidence intervals.

\section{Results and Discussion}

\subsection{Concentration of metals in fish}

The mean concentration of the metals in the reservoir water and the fish gills and muscles are given in Table 1 . The metals with set drinking water guidelines as given by $\mathrm{WHO}^{32}$ had concentrations above the set limits except for $\mathrm{Cu}$. $\mathrm{As}, \mathrm{Pb}$ and Cd concentrations were more than 100, 290 and 500-fold higher than the respective guideline limits. These metals have the potential to accumulate in fish, which in turn becomes a health concern for those that consume the fish. In this regard, all the metals, except $\mathrm{Cr}$, had concentrations in the fish organs above permissible limits defined by various organisations (Table 1). Considering that the bioaccumulation factors (Table 2) were insignificant, the high metal concentrations in fish were related to the observed water concentrations. The water from the Golinga reservoir is also used to irrigate traditional vegetables, with recent studies showing that toxic metals $(\mathrm{Pb}, \mathrm{Cd}, \mathrm{Cr}$, and As) in those vegetables exceeded the $\mathrm{WHO} / \mathrm{FAO}$ guideline limits. ${ }^{33}$

The two fish species have different feeding preferences. ${ }^{34}$ The C. gariepinus fish is an omnivorous predator with a preference

\begin{tabular}{|c|c|c|c|c|c|c|c|c|c|c|}
\hline & As & $\mathrm{Cd}$ & $\mathrm{Fe}$ & Co & $\mathrm{Cr}$ & $\mathrm{Cu}$ & $\mathrm{Mn}$ & Mo & $\mathrm{Ni}$ & $\mathrm{Pb}$ \\
\hline Water $\left(\mathrm{mg} \mathrm{L}^{-1}\right)$ & $1.19 \pm 0.21$ & $1.56 \pm 0.01$ & $5.79 \pm 0.00$ & $0.86 \pm 0.11$ & $0.23 \pm 0.01$ & $0.12 \pm 0.03$ & $0.17 \pm 0.03$ & $0.09 \pm 0.01$ & $0.30 \pm 0.02$ & $2.91 \pm 0.45$ \\
\hline $\begin{array}{l}\text { Drinking water } \\
\text { guideline }\left(\mathrm{mg} \mathrm{L}^{-1}\right)\end{array}$ & 0.01 & 0.003 & $0.5-50^{*}$ & NG & 0.05 & 2 & NG & NG & 0.07 & 0.01 \\
\hline \multicolumn{11}{|c|}{ Fish permissible limits - $\mathrm{mg} \mathrm{L}^{-1}(\mathrm{dw})^{*}$} \\
\hline WHO 1989 & - & 0.19 & 19 & - & 9.5 & 5.7 & 0.19 & - & $0.095-0.19$ & 0.38 \\
\hline FAO 1983 & 0.19 & 0.095 & - & - & - & 5.7 & 1.05 & - & - & 0.095 \\
\hline $\mathrm{EC}$ & - & 0.0095 & - & - & - & - & - & - & - & 0.057 \\
\hline \multicolumn{11}{|l|}{ Oreochromis niloticus } \\
\hline Gills (mg kg-1 dw) & $46.6 \pm 2.43$ & $52.8 \pm 0.23$ & $383 \pm 88.1$ & $18.2 \pm 0.00$ & $7.67 \pm 0.01$ & $33.5 \pm 6.06$ & $141 \pm 14.5$ & $6.40 \pm 1.74$ & $18.0 \pm 1.42$ & $88.3 \pm 8.67$ \\
\hline Muscles $\left(\mathrm{mg} \mathrm{kg}^{-1} \mathrm{dw}\right)$ & $56.4 \pm 1.90$ & $52.5 \pm 0.59$ & $56.2 \pm 0.00$ & $15.1 \pm 2.12$ & $8.32 \pm 1.20$ & $14.1 \pm 0.92$ & $3.39 \pm 0.77$ & $3.69 \pm 0.00$ & $6.96 \pm 0.00$ & $69.7 \pm 15.2$ \\
\hline $\operatorname{EDI}\left(\mu \mathrm{g} \mathrm{kg}^{-1}\right.$ day $\left.^{-1}\right)$ & 5.88 & 5.47 & 5.86 & 1.57 & 0.866 & 1.47 & 0.352 & 0.852 & 0.781 & 7.26 \\
\hline THQ & 19.6 & 5.47 & $1.95 \times 10^{-2}$ & $7.84 \times 10^{-2}$ & $5.78 \times 10^{-4}$ & $3.68 \times 10^{-2}$ & $2.52 \times 10^{-3}$ & $1.89 \times 10^{-2}$ & $3.91 \times 10^{-2}$ & 1.81 \\
\hline TCR & $8.82 \times 10^{-3}$ & $3.44 \times 10^{-2}$ & - & - & $4.33 \times 10^{-4}$ & - & - & - & - & $6.17 \times 10^{-5}$ \\
\hline \multicolumn{11}{|l|}{ Clarias gariepinus } \\
\hline Gills (mg kg-1 dw) & $36.4 \pm 4.47$ & $52.2 \pm 1.59$ & $455 \pm 149$ & $17.2 \pm 3.00$ & $7.80 \pm 0.74$ & $19.0 \pm 0.77$ & $40.6 \pm 3.62$ & $4.40 \pm 2.02$ & $12.5 \pm 0.00$ & $105 \pm 21.1$ \\
\hline Muscles $\left(\mathrm{mg} \mathrm{kg}^{-1} \mathrm{dw}\right)$ & $54.5 \pm 4.67$ & $52.8 \pm 0.87$ & $56.2 \pm 0.00$ & $16.7 \pm 0.00$ & $7.00 \pm 0.11$ & $16.5 \pm 2.59$ & $0.16 \pm 0.03$ & $6.20 \pm 0.23$ & $5.87 \pm 0.29$ & $101 \pm 5.38$ \\
\hline EDI $\left(\mu \mathbf{g ~ k g}^{-1}\right.$ day $\left.^{-1}\right)$ & 5.67 & 5.50 & 5.86 & 1.75 & 0.728 & 1.72 & 0.0162 & 0.645 & 0.611 & 10.5 \\
\hline THQ & 18.9 & 5.50 & $1.95 \times 10^{-2}$ & $8.72 \times 10^{-2}$ & $4.86 \times 10^{-4}$ & $4.30 \times 10^{-2}$ & $1.16 \times 10^{-4}$ & $1.43 \times 10^{-2}$ & $3.06 \times 10^{-2}$ & 2.63 \\
\hline TCR & $8.51 \times 10^{-3}$ & $3.47 \times 10^{-2}$ & - & - & $3.64 \times 10^{-4}$ & - & - & - & - & $8.93 \times 10^{-5}$ \\
\hline \multicolumn{11}{|c|}{ Estimated safe consumption rates $\left(\mathrm{kg} \mathrm{yr}^{-1}\right)$} \\
\hline Oreochromis niloticus & 0.61 & 2.19 & 614 & 153 & 20767 & 326 & 4761 & 634 & 331 & 6.61 \\
\hline Clarias gariepinus & 0.63 & 2.18 & 614 & 137 & 24701 & 279 & 103214 & 836 & 392 & 4.57 \\
\hline Total & 1.25 & 4.37 & 1229 & 290 & 45467 & 605 & 107975 & 1470 & 723 & 11.2 \\
\hline
\end{tabular}
for small organisms, mainly other fish, nematodes, insects and

Table 1 Metal concentration and health risk assessment for fish from the Golinga reservoir

Fish permissible limits converted to dry weight $(\mathrm{dw})$ values using the 0.19 dry weight factor assuming $81 \%$ fish water content; EC = European Commission; EDI = estimated daily intake; THQ = target hazard quotient; TCR = target cancer risk.; NG = no guideline set, * concentration range of $\mathrm{Fe}$ in natural water $\left(\mathrm{mg} \mathrm{L}^{-1}\right)$

Table 2 Fish weight-length relationships for Oreochromis niloticus and Clarias gariepinus

\begin{tabular}{lcccccccccc}
\hline Fish species & $\mathrm{n}$ & $\begin{array}{c}\text { Weight } \\
\text { range }(\mathrm{g})\end{array}$ & $\begin{array}{c}\text { Length } \\
\text { range }(\mathrm{cm})\end{array}$ & $\mathrm{FCW}$ & $\begin{array}{c}\mathrm{RSD} \\
(\%)\end{array}$ & $\mathrm{a}$ & $\mathrm{b}$ & $\log \mathrm{W}=\operatorname{loga}+\operatorname{blogL}$ & $\mathrm{R}^{2}$ & $\mathrm{~W}=\mathrm{aL}^{\mathrm{b}}$ \\
\hline O. niloticus & 20 & $64.4-143$ & $15.1-19.1$ & 1.80 & 8.9 & 0.0062 & 3.37 & $\mathrm{y}=-2.21+3.3708 \mathrm{x}$ & 0.832 & $\mathrm{~W}=0.0062 \mathrm{~L}^{3.37}$ \\
C. gariepinus & 20 & $34.1-113$ & $18.2-26.4$ & 0.60 & 10.8 & 0.0064 & 2.98 & $\mathrm{y}=-2.1905+2.9795 \mathrm{x}$ & 0.925 & $\mathrm{~W}=0.0064 \mathrm{~L}^{2.98}$ \\
\hline
\end{tabular}

$\mathrm{FCF}=$ Fulton's condition factor $\left[\mathrm{FCF}=100 \times \mathrm{W} / \mathrm{L}^{3}\right], \mathrm{W}=$ weight of fish, $\mathrm{L}=$ length of fish, $\mathrm{a}=\mathrm{y}$-intercept parameter, $\mathrm{b}=$ slope parameter 
snails. However, when prey is limited, they will feed on aquatic weeds. On the other hand, O. niloticus is mainly herbivorous and prefers to feed on phytoplankton, algae, detritus and macrophytes. Younger O. niloticus also eat zooplankton, nematodes and insects. While this implies that the metal concentrations in the two fishes may differ, in this study, we observed that the concentrations of $\mathrm{Cd}, \mathrm{Co}$ and $\mathrm{Cr}$ in the two fish species were not significantly different at a $95 \%$ confidence interval. The indication is that the accumulation of metals was not related to the feeding habits or the physiology of the fish species.

On the other hand, the mean concentrations of $\mathrm{Fe}$, Mo and $\mathrm{Ni}$ differed significantly between muscles and gills but remained similar in the organs of the two fish species. Bioaccumulation was more dependent on the organ than the fish species, with preferential accumulation in the gills for these metals. The results show that $\mathrm{Fe}$ was present in the highest concentration in the fish gills. Recording 383 and $455 \mathrm{mg} \mathrm{kg}^{-1}(\mathrm{dw})$ in O. niloticus and $C$. gariepinus, respectively. In muscles, the concentrations were as low as $56.2 \mathrm{mg} \mathrm{kg}^{-1}$. The distribution pattern for Fe in fish has been reported elsewhere for different fish species. The authors recorded $379.439 \mathrm{mg} \mathrm{kg}^{-1}$ in gills versus $12.494 \mathrm{mg} \mathrm{kg}^{-1}$ in muscles of Acipenser ruthenus in Serbia. ${ }^{35}$

The concentrations of $\mathrm{Cu}, \mathrm{Mn}$, As and Ni were significantly different between the gills of the two fish species, preferentially accumulating in $O$. niloticus. The $C$. gariepinus fish tends to emerge out of the water, close its gills and breathe air via its mouth into specialised breathing organs other than the gills. In addition, $\mathrm{Pb}$ was high in the organs of $\mathrm{C}$. gariepinus, which might be related to its carnivorous feeding habits.

The study has also observed that most metal concentrations were highest in gills, except for As (Table 1). Fish gills are more susceptible to metal ions dissolved in their aquatic habitats through ion exchange during breathing. Fish continuously pass water through their gills to absorb oxygen dissolved in water. However, the gill filaments have a very large surface area. Other chemical ions, including metals, get absorbed, which might explain the high levels of metals in gills reported in this study. The preference for metal bioaccumulation in organs other than the muscles is a welcome observation because the muscle is the only consumed organ in fish. A higher concentration of As in fish muscles than gills has been reported in literature for various fish species, including Cyprinus carpio and Acipenser ruthenus in Serbia ${ }^{8,34}$ and Silurus glanis in Italy. ${ }^{36}$ For example, the mean concentration in muscle tissues of the Silurus glanis was $0.06 \mathrm{mg} \mathrm{kg}^{-1}$ versus $0.01 \mathrm{mg} \mathrm{kg}^{-1}$ in gills..$^{36} \mathrm{~A}$ higher concentration of As in the gills than muscles has also been reported in the Poyang Lake, China ${ }^{10}$ and the Danube River, Serbia. ${ }^{9}$

Generally, the concentrations of metals reported in muscles of $C$. gariepinus and O. niloticus fish species in the current study are higher than what has been reported elsewhere for the same fish species from different habitats. ${ }^{21,24,28,37,38}$ In addition, the concentrations are also higher than those reported for other fish species across the world. ${ }^{3,8-10,15,16,29,35,39}$ For example, most metal concentrations were below detection limits in studies done on six different fish species collected from the Mediterranean coast of Turkey ${ }^{11}$ and seven fish species in Malaysia. ${ }^{39}$ However, similar concentrations have been detected in Brycinus longipinnis from Benin River, Nigeria ${ }^{27}$ while very high concentrations of $\mathrm{Cu}$ (1065.50 $\left.\mathrm{mg} \mathrm{kg}^{-1}(\mathrm{dw})\right)$ have been reported in Cynoglossurs arel fish in the Persian Gulf. ${ }^{5}$

\subsection{Fish condition}

The fish condition factors based on weight and length of 20 of each of the fish species are given in Table 2. Expectedly, C. gariepinus with a characteristic elongated posture was significantly longer at a $95 \%$ confidence interval than O. niloticus, whose posture was rather compressed and compact. Inversely, the average weight of $O$. niloticus $(82.0 \mathrm{~g})$ was significantly higher than that of C. gariepinus (64.7 g) at a 95\% confidence interval. Compared to literature, longer and heavier O. niloticus fish have been reported in the Langat River and Engineering Lake in Malaysia, where between 20 and $22 \mathrm{~cm}$, and 220 to $240 \mathrm{~g}$ was recorded. ${ }^{24}$ The weight-length relationships and their linear forms for the two fish species are given in Table 2. Despite the metal concentrations in the reservoir above the WHO drinking water guideline limits (Table 1), the O. niloticus condition parameters (the $b$ parameter and the FCF) were comparable with the standard values indicating that this fish species was growing isometrically. A healthy fish is more likely to perform normal activities, including reproduction which becomes essential in sustaining the communities that rely on the fish as a food source. Fish population studies at the Golinga reservoir may be done to confirm this supposition.

On the other hand, the condition parameters for C. gariepinus were below the standard values indicating that this fish species was experiencing growth challenges in the reservoir. Other contributing factors may include other pollutants and food availability with considerations that $C$. gariepinus prefers small mammals and other fish as a food source. Elsewhere, based on weight-length relationships, healthy fish have been reported in the Olsztyn Lake, Poland.22 At the same time, negative growth has also been observed for Diplodus sargus, Diplodus puntazzo and Pagrus caeruleostictus in Tripoli-Lebanon. ${ }^{40}$

\subsection{Metal bioaccumulation}

The bioaccumulation factors for metal uptake (Table 3 and Fig. 1) confirmed that the accumulation of metals in the fish from the Golinga reservoir were insignificant with the calculated BF values below 100, except for $\mathrm{Mn}$, whose BF value in O. niloticus gills was 161. Limited bioaccumulation of metals, especially heavy metals, is essential in keeping the consumers at low risk for potential health side effects due to fish consumption from aquatic systems polluted with metal ions. Insignificant bioaccumulation of metals in fish has also been observed in seven fish species in the Ganga river, India. ${ }^{23}$ Elsewhere, a study on eight different fish species in the Taihu lake in

Table 3 Bioaccumulation factors

\begin{tabular}{lcccccccccc}
\hline Species and organ & $\mathrm{As}$ & $\mathrm{Cd}$ & $\mathrm{Fe}$ & $\mathrm{Co}$ & $\mathrm{Cr}$ & $\mathrm{Cu}$ & $\mathrm{Mn}$ & $\mathrm{Mo}$ & $\mathrm{Ni}$ & $\mathrm{Pb}$ \\
\hline O. niloticus muscles & 9.0 & 6.4 & 1.8 & 3.3 & 6.9 & 22 & 3.9 & 18 & 4.4 & 4.6 \\
O. niloticus gills & 7.5 & 6.4 & 13 & 4.0 & 6.4 & 51 & 161 & 14 & 11 & 5.8 \\
C. gariepinus muscles & 8.7 & 6.4 & 1.8 & 3.7 & 5.8 & 25 & 0.18 & 14 & 3.7 & 6.6 \\
C. gariepinus gills & 5.8 & 6.4 & 15 & 3.8 & 6.5 & 29 & 46 & 15 & 7.9 & 6.9 \\
\hline
\end{tabular}

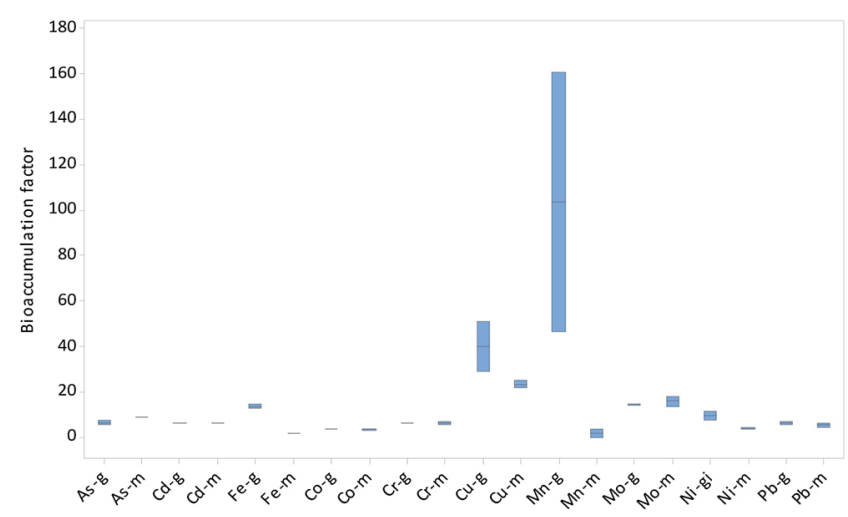

Figure 1 Boxplot for bioaccumulation factors of metals in gills (g) and muscles $(\mathrm{m})$ of Oreochromis niloticus and Clarias gariepinus fish in the Golinga reservoir 
China observed $\mathrm{BF}$ values higher than 100 , with $\mathrm{Pb}$ reaching 6260 in Aristichthys nobilis. ${ }^{30}$ Subotic et al. ${ }^{9}$ observed varying bioconcentration factors among four different fish species in the Danube River, Serbia. In their study, the accumulation of a single metal in different species varied significantly. For example, accumulation factors for As in the muscles of Lota lota and Cyprinus carpio were 197.27 and 223.64, respectively, while Sander lucioperca and Silurus glanis had BF $\leq 36$.

\subsection{Health risk assessment}

The health risk assessment studies on the consumed fish muscles are presented in Table 1. Despite most metal concentrations in the edible fish muscles being above the permissible levels, their THQ values were still below one except for three heavy metals; $\mathrm{Pb}, \mathrm{Cd}$ and As. The THQ values for these metals were above 1 for both fish species implying potential health risks due to consumption of the fish from the Golinga reservoir over one's lifetime. The THQ values were predicted based on the per capita consumption of fish in Ghana currently estimated at $28 \mathrm{~kg} \mathrm{yr}^{-1}$ and assuming that the value is additive due to consumption of the two fish species at equal rates. The metal with the highest THQ value was As (THQ = 19.6), which was related to high estimated daily doses compared to its reference dose. Other studies have also identified possible risks with THQ $>1$ for Cd, Cr and As. ${ }^{5,12,26,39,41}$ High THQ values for As similar to the current study, have been reported in Cynoglossurs arel fish species in the Persian Gulf where the values were up to 169.888. ${ }^{5}$ In Nigeria, the THQ values for most metals were below one except for $\mathrm{Pb}$, which was $1.41 .^{27}$ However, studies have reported a low risk of exposure to metal toxicities (THQ $<1$ ) due to fish consumption from the Langat River and Engineering Lake in Malaysia ${ }^{24}$ and Poyang Lake in China ${ }^{10}$.

The TCR values for $\mathrm{As}, \mathrm{Cd}, \mathrm{Cr}$ and $\mathrm{Pb}$ were all above the nonrisk threshold of TCR $\leq 10^{-6}$ and fell in the range of $6.17 \times 10^{-5}(\mathrm{~Pb})$ to $3.47 \times 10^{-2}(\mathrm{Cd})$, implying that consumption of the fish from the Golinga reservoir at an average rate of $28 \mathrm{~kg} \mathrm{yr}^{-1}$ has moderate chances of causing cancer over the years. The metal concentration in the fish in the reservoir should therefore be constantly monitored, especially As $\left(\mathrm{TCR}=10^{-3}\right)$ and $\mathrm{Cd}$ $\left(\mathrm{TCR}=10^{-2}\right.$ ) because the fish are the main source of proteins for most communities in the Northern region of Ghana. TCR values of 1.34 to $7.17 \times 10^{-4}$ have been reported for As in fish from the Corsican coast of the Mediterranean sea ${ }^{25}, 7.63 \times 10^{-3}$ to $4.04 \times 10^{-4}$ in fish from the Persian Gulf ${ }^{5}$ and $1.6 \times 10^{-3}$ to $6.6 \times 10^{-5}$ in fish from the Mediterranean sea ${ }^{41}$. The average TCR values for $\mathrm{As}$ and $\mathrm{Pb}$ were $5.71 \times 10^{-4}$ and $2.42 \times 10^{-5}$, respectively, in sixteen fish species of the Mediterranean sea consumed in Turkey. ${ }^{11}$ Another study has reported TCR $<10^{-5}$ for $\mathrm{As}$ (and $\mathrm{Cd}$ ) while for $\mathrm{Pb}$, the value was $<10^{-6}$, implying that fish from that aquatic system was relatively safe for lifetime consumption ${ }^{42}$. In four fish species from Chenab River, Pakistan, the TCR values for $\mathrm{Cr}$ and $\mathrm{Pb}$ were within the safe range while values for As were not safe. ${ }^{30}$

The estimated safe consumption rates (Table 1) showed that the total yearly consumption of the two fish species from the Golinga region should not exceed $1.25 \mathrm{~kg} \mathrm{yr}^{-1}$ per person mainly due to potential As health effects. $\mathrm{Cd}$ and $\mathrm{Pb}$ also had estimated safe consumption rates lower than the per capita consumption of fish in Ghana, currently estimated at $28 \mathrm{~kg} \mathrm{yr}^{-1}$ per person ${ }^{1}$. However, the estimated safe consumption rates for most metals were higher than the per capita consumption. The implication is that the population remains at low risk due to other metals except $\mathrm{As}, \mathrm{Cd}$ and $\mathrm{Pb}$.

\section{Conclusions}

In this study, health risk assessment due to consumption of two fish species (Oreochromis niloticus and Clarias gariepinus), breeding naturally in the Golinga reservoir and consumed by communities in the Northern region of Ghana, was conducted. The results showed that the selected metals in the reservoir were higher than the $\mathrm{WHO}$ drinking water guideline limits. In turn, the concentrations in the fish were also higher than most international guideline limits. However, these metals bioaccumulated preferentially in the gills compared to the edible parts. Most of the metals that had accumulated in the edible muscles of the fish have limited potential for human health risks in one's lifetime, except for $\mathrm{As}, \mathrm{Cr}, \mathrm{Cd}$ and $\mathrm{Pb}$. These four heavy metals may cause carcinogenic effects due to As and $\mathrm{Cd}$, while potential non-carcinogenic effects may occur due to $\mathrm{Pb}$ and $\mathrm{Cr}$. The fish of the Golinga reservoir is an important source of protein for the local communities. Therefore, continuous monitoring of pollutant accumulation in the fish of the Golinga reservoir is required, and where possible, protocols should be drafted to protect the communities from potential health effects. Currently, the estimated safe fish consumption rates that would ensure the population is safe from potential carcinogenic effects due to $\mathrm{As}, \mathrm{Cr}, \mathrm{Cd}$ and $\mathrm{Pb}$ are well below the per capita consumption of fish in Ghana.

\section{Acknowledgements}

The study was funded by UNESCO/KEIZO OBUCHI Yong Research Fellowship (2018 cycle) awarded to Z. Naangmenyele in collaboration with CSIR-Water Research Institute, Ghana

\section{ORCID iDs}

Zita Naangmenyele: https://orcid.org/0000-0001-9432-4230

Somandla Ncube: https://orcid.org/0000-0002-3190-2504

Felix J. Akpabey: https://orcid.org/0000-0002-1941-1403

Simiso Dube: https://orcid.org/0000-0003-1225-5812

Mathew Muzi Nindi: https://orcid.org/0000-0001-7222-1505

\section{References}

1 FAO, Fisheries \& Aquaculture - Fishery and Aquaculture country rofiles - The Republic of Ghana", http://Www.Fao.Org/Fishery/Facp/ GHA/En., 2019. Accessed 29 July 2020.

2 Ghana Statistical Service, Population and housing census, 2014, 1-85. www.statsghana.gov.gh. Accessed 19 August 2020

3 H.M. Leung, A.O.W. Leung, H.S. Wang, K.K. Ma, Y. Liang, K.C. Ho, K.C. Cheung, F. Tohidi, K.K.L. Yung, Assessment of heavy metals/ metalloid ( $\mathrm{As}, \mathrm{Pb}, \mathrm{Cd}, \mathrm{Ni}, \mathrm{Zn}, \mathrm{Cr}, \mathrm{Cu}, \mathrm{Mn}$ ) concentrations in edible fish species tissue in the Pearl River Delta (PRD), China, Mar. Pollut. Bull., 2014, 78, 235-245.

$4 \mathrm{FAO} / \mathrm{WHO}$, Working document for Information and use in discussion related to contaminants and toxins in the GSCTFF, Jt. FAO/WHO Food Stand. Program. Codex Comm. Contam. Foods., 2011, 1-90. https://doi.org/10.3768/rtipress.2014.rb.0007.1405.

5 B. Keshavarzi, M. Hassanaghaei, F. Moore, M. Rastegari, S. Soltanian, A. Reza, A. Sorooshian, Heavy metal contamination and health risk assessment in three commercial fish species in the Persian Gulf, Mar. Pollut. Bull., 2018, 129, 245-252.

6 F.K. Görür, R. Keser, N. Akçay, S. Dizman, Radioactivity and heavy metal concentrations of some commercial fish species consumed in the Black Sea Region of Turkey, Chemosphere, 2012, 87, 356-361.

7 B. Milenkovic, J.M. Stajic, N. Stojic, M. Pucarevic, S. Strbac, Evaluation of heavy metals and radionuclides in fish and seafood products, Chemosphere, 2019, 229, 324-331.

8 L. Cai, Q. Wang, J. Luo, L. Chen, R. Zhu, S. Wang, C. Tang, Heavy metal contamination and health risk assessment for children near a large Cu-smelter in Central China, Sci. Total Environ., 2019, 650, 725-733.

9 S. Subotić, S. Spasić, Ž. Višnjić-Jeftić, A. Hegediš, J. Krpo-Ćetković, B. Mićković, S. Skorić, M. Lenhardt, Heavy metal and trace element bioaccumulation in target tissues of four edible fish species from the Danube River (Serbia), Ecotoxicol. Environ. Saf., 2013, 98, 196-202. 
10 Y. Wei, J. Zhang, D. Zhang, T. Tu, L. Luo, Metal concentrations in various fish organs of different fish species from Poyang Lake, China, Ecotoxicol. Environ. Saf., 2014, 104, 182-188.

11 C. Korkmaz, Ö. Ay, Y. Ersoysal, M. Ali, C. Erdem, Heavy metal levels in muscle tissues of some fish species caught from North- East Mediterranean: Evaluation of their effects on human health, J. Food Compos. Anal., 2019, 81, 1-9.

12 D.K. Bastami, M. Afkhami, M. Mohammadizadeh, M. Ehsanpour, S. Chambari, S. Aghaei, M. Esmaeilzadeh, R.M. Neyestani, F. Lagzaee, M. Baniamam, Bioaccumulation and ecological risk assessment of heavy metals in the sediments and mullet Liza klunzingeri in the northern part of the Persian Gulf, Mar. Pollut. Bull., 2015, 94, 329-334.

13 P. Morcillo, M.Á. Esteban, A. Cuesta, Heavy metals produce toxicity, oxidative stress and apoptosis in the marine teleost fish SAF-1 cell line, Chemosphere, 2016, 144, 225-233.

14 F.A. Monikh, A. Safahieh, A. Savari, A. Doraghi, Heavy metal concentration in sediment, benthic, benthopelagic, and pelagic fish species from Musa Estuary (Persian Gulf), Environ. Monit. Assess., 2013, 185, 215-222.

15 B.J. Richardson, A. Velusamy, P.S. Kumar, A. Ram, S. Chinnadurai, Bioaccumulation of heavy metals in commercially important marine fishes from Mumbai Harbor, India, Mar. Pollut. Bull., 2014, 81, 218224.

16 A.A. Fallah, S.S. Saei-dehkordi, A. Nematollahi, T. Jafari, Comparative study of heavy metal and trace element accumulation in edible tissues of farmed and wild rainbow trout (Oncorhynchus mykiss) using ICP-OES technique, Microchem., 2011, 98, 275-279.

17 R.J. Medeiros, M.L. dos Santos, A.S. Freire, R.E. Santelli, A. Braga, Maria, T.M. Krauss, S. do C. Jacob, Determination of inorganic trace elements in edible marine fish from Rio de Janeiro, Brazil, Food Control, 2012, 23, 535-541.

18 M. Fatima, N. Usmani, M.M. Hossain, Assessment of genotoxic induction and deterioration of fish quality in commercial species due to heavy-metal exposure in an urban reservoir, Arch Env. Contam Toxicol., 2014, 67, 203-213.

19 D.G. Sfakianakis, E. Renieri, M. Kentouri, A.M. Tsatsakis, Effect of heavy metals on fish larvae deformities: A review, Environ. Res., 2015, 137, 246-255.

20 N. Bilandzic, M. Đokic, M. Sedak, Metal content determination in four fish species from the Adriatic Sea, Food Chem., 2011, 124, 1005-1010.

21 I.O. Ayanda, U.I. Ekhator, O.A. Bello, Determination of selected heavy metal and analysis of proximate composition in some fish species from Ogun River, Southwestern Nigeria, Heliyon, 2019, 5, e02512.

22 J. Łuczyńska, B. Paszczyk, M.J. Łuczyński, Fish as a bioindicator of heavy metals pollution in aquatic ecosystem of Pluszne Lake, Poland, and risk assessment for consumer's health, Ecotoxicol. Environ. Saf., 2018, 153, 60-67.

23 K.P. Maurya, D.S. Malik, K.K. Yadav, A. Kumar, S. Kumar, H. Kamyab, Bioaccumulation and potential sources of heavy metal contamination in fi sh species in River Ganga basin: Possible human health risks evaluation, Toxicol. Reports, 2019, 6, 472-481.

24 A. Taweel, A.K. Ahmad, Assessment of heavy metals in tilapia fish (Oreochromis niloticus) from the Langat River and Engineering Lake in Bangi, Malaysia, and evaluation of the health risk from tilapia consumption, Ecotoxicol. Environ. Saf., 2013, 93, 45-51.

25 M. Marengo, E.D.H. Durieux, S. Ternengo, P. Lejeune, E. Degrange, Comparison of elemental composition in two wild and cultured marine fi sh and potential risks to human health, Ecotoxicol. Environ. Saf., 2018, 158, 204-212.

26 P. Cretì, F. Trinchella, Heavy metal bioaccumulation and metallothionein content in tissues of the sea bream Sparus aurata from three different fish farming systems, Env. Monit Assess., 2010, $165,321-329$.
27 L.I. Ezemonye, P.O. Adebayo, A.A. Enuneku, I. Tongo, E. Ogbomida, Potential health risk consequences of heavy metal concentrations in surface water, shrimp (Macrobrachium macrobrachion) and fish (Brycinus longipinnis) from Benin River, Nigeria, Toxicol. Reports., 2019, 6, 1-9.

28 Y. Nuapia, L. Chimuka, E. Cukrowska, Assessment of heavy metals in raw food samples from open markets in two African cities, Chemosphere, 2018, 196, 339-346.

29 Y. Tao, Z. Yuan, H. Xiaona, M. Wei, Distribution and bioaccumulation of heavy metals in aquatic organisms of different trophic levels and potential health risk assessment from Taihu lake, China, Ecotoxicol. Environ. Saf., 2012, 81, 55-64.

30 A. Alamdar, S. Ali, M. Akber, S. Eqani, N. Hanif, S. Maria, M. Fasola, H. Bokhari, I.A. Katsoyiannis, H. Shen, Human exposure to trace metals and arsenic via consumption of fish from river Chenab, Pakistan and associated health risks, Chemosphere, 2017, 168, 1004-1012.

31 W.C. Driscoll, Robustness of the ANOVA and Tukey-Kramer statistkal tests, Comput. Ind. Eng., 1996, 31, 265-268.

$32 \mathrm{WHO}$, Guidelines for drinking water quality, 2004. https://doi. org/10.1016/0143-1471(85)90051-0.

33 Z. Naangmenyele, S. Ncube, FJ. Akpabey, S. Dube, M.M. Nindi, Levels and potential health risk of elements in two indigenous vegetables from Golinga irrigation farms in the Northern Region of Ghana, J. Food Compos. Anal., 2020, 96, 103750.

$34 \mathrm{FAO}$, Natural food and feeding habits. http://www.Fao.Org/Fishery/ Affris/Species-Profiles. Accessed 29 July 2020.

35 I. Jaric, Ž. Višnjić-Jeftić, G. Cvijanović, Z. Gačić, L. Jovanovi, S. Skoric, M. Lenhardt, Determination of differential heavy metal and trace element accumulation in liver, gills, intestine and muscle of sterlet (Acipenser ruthenus) from the Danube River in Serbia by ICP-OES, Microchem., 2011, 98, 77-81.

36 S. Squadrone, M. Prearo, P. Brizio, S. Gavinelli, M. Pellegrino, T. Scanzio, S. Guarise, A. Benedetto, M.C. Abete, Heavy metals distribution in muscle, liver, kidney and gill of European catfish (Silurus glanis) from Italian Rivers, Chemosphere, 2013, 90, 358-365.

37 S.M.M. Nakayama, Y. Ikenaka, K. Muzandu, Heavy metal accumulation in Lake sediments, fish (Oreochromis niloticus and Serranochromis thumbergi) and crayfish (Cherax quadricarinatus) in Lake Itezhi-tezhi and Lake Kariba, Zambia, Arch. Environ. Contam. Toxicol., 2010, 59, 291-300.

38 M.L. Asare, S.J. Cobbina, FJ. Akpabey, A.B. Duwiejuah, Z.N. Abuntori, Heavy metal concentration in water, sediment and fish species in the bontanga reservoir, Ghana, Toxicol. Environ. Health Sci., 2018, 10, 49-58.

39 A. Anandkumar, R. Nagarajan, K. Prabakaran, C.H. Bing, R. Rajaram, Human health risk assessment and bioaccumulation of trace metals in fish species collected from the Miri coast, Sarawak, Borneo, Mar. Pollut. Bull., 2018, 133, 655-663.

40 N. Jisr, G. Younes, C. Sukhn, M.H. El-dakdouki, Length-weight relationships and relative condition factor of fish inhabiting the marine area of the Eastern Mediterranean city, Egypt. J. Aquat. Res., 2018, 44, 299-305.

41 C. Copat, G. Arena, M. Fiore, C. Ledda, R. Fallico, S. Sciacca, Heavy metals concentrations in fish and shellfish from eastern Mediterranean Sea: Consumption advisories, Food Chem. Toxicol., 2013, 53, 33-37.

42 C. Vieira, S. Morais, S. Ramos, C. Delerue-matos, M.B.P.P. Oliveira, Mercury, cadmium, lead and arsenic levels in three pelagic fish species from the Atlantic Ocean: Intra- and inter-specific variability and human health risks for consumption, Food Chem. Toxicol., 2011, 49, 923-932. 